\section{Vermicompost Leachate Alleviates Deficiency of Phosphorus and Potassium in Tomato Seedlings}

\author{
Georgina D. Arthur \\ Department of Nature Conservation, Mangosuthu University of Technology, \\ P.O. Box 12363, Jacobs 4026, Durban, South Africa
}

Adeyemi O. Aremu, Manoj G. Kulkarni, and Johannes Van Staden ${ }^{1}$

Research Centre for Plant Growth and Development, School of Life Sciences, University of KwaZulu-Natal Pietermaritzburg, Private Bag X01, Scottsville 3209, South Africa

Additional index words. food security, organic fertilizer, vegetable crop, Lycopersicon esculentum

\begin{abstract}
As a result of the growing concerns about the adverse effect of chemicals on the environment, agricultural practices involving organic and environmental-friendly compounds are gaining acceptance globally. Tomatoes remain one of the most popular and widely grown vegetable crops. However, their growth requires a high supplement of nitrogen-phosphorus-potassium (NPK) fertilizer. The effectiveness of vermicompost leachate (VCL) as a potential replacement for the three elements $(\mathrm{N}, \mathrm{P}$, and $\mathrm{K})$ during the growth of greenhouse tomatoes was evaluated. Morphological appearance of the tomato seedlings was remarkably enhanced when Hoagland's nutrient solution $(50 \%)$ was supplemented with VCL $(1: 10 \mathrm{v} / \mathrm{v})$. In the absence of both $P$ and $K$, the addition of VCL significantly $(P=0.05)$ increased various growth parameters such as shoot length, leaf number as well as shoot and root fresh weight compared with the control tomato seedlings. The detrimental effect of $\mathbf{N}$ deficiency on the growth of tomato seedlings was not alleviated with the addition of VCL to the nutrient solution. The photosynthetic pigment content in P-deficient and VCL-supplemented tomato seedlings was significantly higher than the untreated control. The presence of VCL alleviated the detrimental effects caused by deficiency of $P$ and $K$ during the growth of the tomato seedlings. Overall, the use of VCL was beneficial with either complete nutrient solution or in the absence of $P$ and K. Findings of this study suggest that VCL could serve as a potential substitute for $P$ and $K$ deficiency.
\end{abstract}

The human population is continuously increasing and by the year 2050, the global population is projected to be $50 \%$ larger than the current figure. The available natural resources such as arable land and water required to support the human race are limited. To further worsen the situation, most of the soils in sub-Saharan African countries are characterized by low organic matter content and low fertility coupled with essential macroand microelement deficiency. Thus, there is a need for efficient use of the available land and water for sustainable agricultural production (Tilman et al., 2002; Welch and Graham, 1999). Inevitably, the nutrient-deficient soils need to be supplemented with fertilizers to

Received for publication 4 May 2012. Accepted for publication 26 June 2012.

The University of KwaZulu-Natal, Pietermaritzburg, and Mangosuthu University of Technology, Durban, South Africa, provided financial support.

We appreciate the technical assistance of Mrs. Alison Young (University of KwaZulu-Natal, Botanical Garden, Pietermaritzburg) and her staff during the greenhouse experiment.

${ }^{1}$ To whom reprint requests should be addressed; e-mailrcpgd@ukzn.ac.za. promote growth and yield of major crops to curb possible food shortages. Besides, intensive high-yield agriculture production depends on the application of fertilizers, especially industrially produced ammonium and nitrate (Lyson, 2002; Tilman et al., 2002). In most developing countries, however, the inorganic fertilizers are expensive and not easily accessible to many small-scale farmers (Welch and Graham, 1999). Furthermore, an increase in the use of inorganic fertilizers for improved crop production has been linked to increased health hazards to humans and livestock as well as causing severe environmental problems such as water and soil pollution, which are generally considered detrimental (Alam et al., 2007).

Good agricultural practices determine the level of food production and, to a great extent, the state of the global environment (Lyson, 2002). The use of sustainable agricultural sources and the environment remains a viable option to increase agricultural product output (Lazcano et al., 2011). Consequently, scientists are continuously exploring means of improving crop yield and quality without compromising environmental integrity or public health (Lockie et al., 2002; Sangwan practices that entail the conservation of re- et al., 2010; Tilman et al., 2002). Recently, there has been an increase in demand for such naturally derived agroproducts for sustainable farming systems (Campitelli and Ceppi, 2008; Suthar, 2010).

Reliance on organic nutrient sources is an essential characteristic of organic farming. For instance, the use of organic fertilizers, in the form of vermicompost, is one such practical example of a compound used for sustainable agricultural farming (Alam et al., 2007; Gutiérrez-Miceli et al., 2008). Vermicomposts including their leachates, teas, and other extracts are produced by the activity of earthworms from a wide range of organic wastes (Gutiérrez-Miceli et al., 2008; Ievinsh, 2011; Padmavathiamma et al., 2008; Wang et al., 2010). They are products of non-thermophilic biodegradation of complex organic waste resources into peat-like humus, which are finely divided and odorless (Arancon et al., 2003; Sangwan et al., 2010). There is rising acceptance of vermicompost as a result of numerous benefits derivable from their use as plant growth media and soil ameliorants (Bachman and Metzger, 2008; Tomati et al., 1990; Wang et al., 2010). Recently, the positive effect of soil drenching with vermicompost leachate on the growth of greenhouse-grown 'Williams' bananas was demonstrated (Aremu et al., 2012).

Globally, tomato is recognized as one of the most popular and widely grown vegetable crops. It is easily grown in greenhouses, responds well to the application of fertilizers, and is known to be a heavy consumer of N-P-K fertilizer (Hebbar et al., 2004). Different approaches have been geared toward improving the growth of tomatoes (Lammerts van Bueren et al., 2011; Roosta and Hamidpour, 2011; Sato et al., 2006). The current study evaluated the effects of vermicompost leachate drenching treatments on the growth of tomato seedlings under greenhouse conditions as a potential replacement of essential macroelements such as $\mathrm{N}, \mathrm{P}$, and $\mathrm{K}$. The effect of vermicompost leachate on growth parameters and its influence on the photosynthetic pigment contents were evaluated.

\section{Materials and Methods}

The experiments were conducted using commercial seeds of tomato (Lycopersicon esculentum Mill. 'Heinz-1370') purchased from McDonald's Seed Company, Pietermaritzburg, South Africa. VCL was obtained from Wizzard Worms, Rietvlei, KwaZuluNatal, South Africa. Hoagland's nutrient solution $(50 \%)$ was used for the experiment (Hoagland and Snyder, 1933). Three other test solutions were prepared by eliminating $\mathrm{N}$, P, or $\mathrm{K}$ from the Hoagland's nutrient solution. On 27 Jan. 2012, three tomato seeds were sown at a depth of $1 \mathrm{~cm}$ in each pot $(100 \mathrm{~mL})$ containing perlite as a substrate. Thereafter, pots were regularly watered for 3 weeks for raising seedlings. Subsequently, a single seedling was retained in each pot by uprooting the other two seedlings. Each treatment had 10 pots with four replicates 
arranged randomly on the greenhouse benches. Each seedling was treated (drenched) with $10 \mathrm{~mL}$ of VCL on 16, 26, and 8 Feb. to Mar. 2012. At the same time, respective control seedlings (grown without $\mathrm{N}, \mathrm{P}, \mathrm{K}$, and VCL) were supplied with $10 \mathrm{~mL}$ of distilled water. Hoagland's nutrient solution $(50 \%)$ with or without $\mathrm{N}, \mathrm{P}$, or $\mathrm{K}$ was added $(100 \mathrm{~mL})$ to respective pots twice weekly for 4 weeks. During the trial, the greenhouse had $60 \%$ relative humidity and $25 / 15{ }^{\circ} \mathrm{C}$ day/night temperature with an average photosynthetic photon flux density of $450 \mu \mathrm{mol} \cdot \mathrm{m}^{-2} \cdot \mathrm{s}^{-1}$. The experiment was ended on 16 Mar. 2012. Tomato seedlings were harvested, washed, and air-dried. Subsequently, the vegetative parameters such as number (leaf, shoot and root), length (shoot and root), and fresh weights (shoot and root) were measured. Dry weights of the harvested plant parts were determined after the fresh materials were ovendried at $70 \pm 2{ }^{\circ} \mathrm{C}$ for $5 \mathrm{~d}$.

Using freshly harvested tomato leaves, the level of chlorophyll a, chlorophyll b, and total carotenoid content was evaluated as described by Lichtenthaler (1987). Briefly, $5 \mathrm{~mL}$ of acetone with $0.1 \mathrm{~g}$ of leaf material from each treatment was homogenized using a mortar and pestle. The resultant mixture was separated using a benchtop centrifuge (Hettich Universal, Tuttlingen, Germany) at $5000 \mathrm{rpm}$ for $5 \mathrm{~min}$ at room temperature. The absorbance of the filtrate was recorded at 470 , 645 , and $662 \mathrm{~nm}$ with a spectrophotometer (Varian Cary 50, Australia). The photosynthetic pigment content expressed as $\mu \mathrm{g} \cdot \mathrm{g}^{-1}$ fresh weight was determined using the formulae used by Lichtenthaler (1987):
Chlorophyll a $\left(\mathrm{C}_{\mathrm{a}}\right)=11.24 \mathrm{~A}_{662}-2.04 \mathrm{~A}_{645}$ Chlorophyll $\mathrm{b}\left(\mathrm{C}_{\mathrm{b}}\right)=20.13 \mathrm{~A}_{645}-4.19 \mathrm{~A}_{662}$ Total chlorophylls $=7.05 \mathrm{~A}_{662}+18.09 \mathrm{~A}_{645}$ Total carotenoids $=\left(1000 \mathrm{~A}_{470}-1.90 \mathrm{C}_{\mathrm{a}}\right.$ $\left.\left.-63.14 \mathrm{C}_{\mathrm{b}}\right) / 214\right)$

Data were subjected to one-way analysis of variance using SPSS software package for Windows (SPSS ${ }^{\circledR}$, Version 10.0, Chicago, IL). Where there was statistical significance $(P=$ $0.05)$, the mean values were further separated using the Duncan's multiple range test.

\section{Results}

The responses of the greenhouse-grown tomatoes in terms of quantitative and morphological growth parameters are shown in Figures 1 and 2. Supplementing the nutrient solution with VCL had a significant effect on growth and development of the tomato seedlings (Figs. 1A, 1C, and 1D). Overall, addition of VCL with nutrient solution of $\mathrm{K}$ proved to be the best treatment regime. The $\mathrm{N}$ nutrient solution was detrimental and even the addition of VCL had no significant effect on the growth of the greenhouse tomatoes (Figs. 1 and 2).

The shoot length ranged from $\approx 34$ to 131 $\mathrm{mm}$ as observed in $\mathrm{N}$ and $\mathrm{K}+\mathrm{VCL}$ treatments, respectively (Fig. 1A). When compared with their respective controls (with the exception of $\mathrm{N}$ ), the application of VCL resulted in a significant $(P=0.05)$ increase in the shoot length of the tomato seedlings. A similar trend was observed for the shoot fresh and dry weights (Figs. 1C and 1E) as well as root fresh and dry weights (Figs. 1D and $1 \mathrm{~F}$ ). Besides the significantly $(P=0.05)$ longer roots in P + VCL treatment, other VCL-treated tomato seedlings were not significantly different from their respective control (Fig. 1B).

The results of number of leaves and amount of photosynthetic pigment in the tomato seedlings are shown in Table 1. The highest number of leaves was produced in nutrient solution of K + VCL, which was significantly different from its control. On the other hand, the lowest number of leaves was observed in the $\mathrm{N}$ treatments. The $\mathrm{K}$ (control) treatment had the highest level of chlorophyll a, chlorophyll b, and carotenoid, whereas $\mathrm{N}$ (both control and VCL-treated) nutrient solution had a detrimental effect on the photosynthetic pigment content. In comparison with the control, the amount of photosynthetic pigment was higher when VCL was added to P nutrient solution. Tomato seedlings with the best chlorophyll $\mathrm{a} / \mathrm{b}$ ratio were obtained in $\mathrm{N}$ and VCL-supplemented solutions. The highest total chlorophyll/carotenoid ratio was recorded for seedlings treated with $\mathrm{K}$ nutrient solution.

\section{Discussion}

Studies on the germination, growth, and improved production of tomatoes remain of great concerns to researchers globally, because it is a major vegetable crop (Ievinsh, 2011; Paul and Metzger, 2005; Premuzic et al., 1998; Surrage et al., 2010). Although there are numerous studies on tomato research, efforts geared toward maximizing the input of resources such as limited land
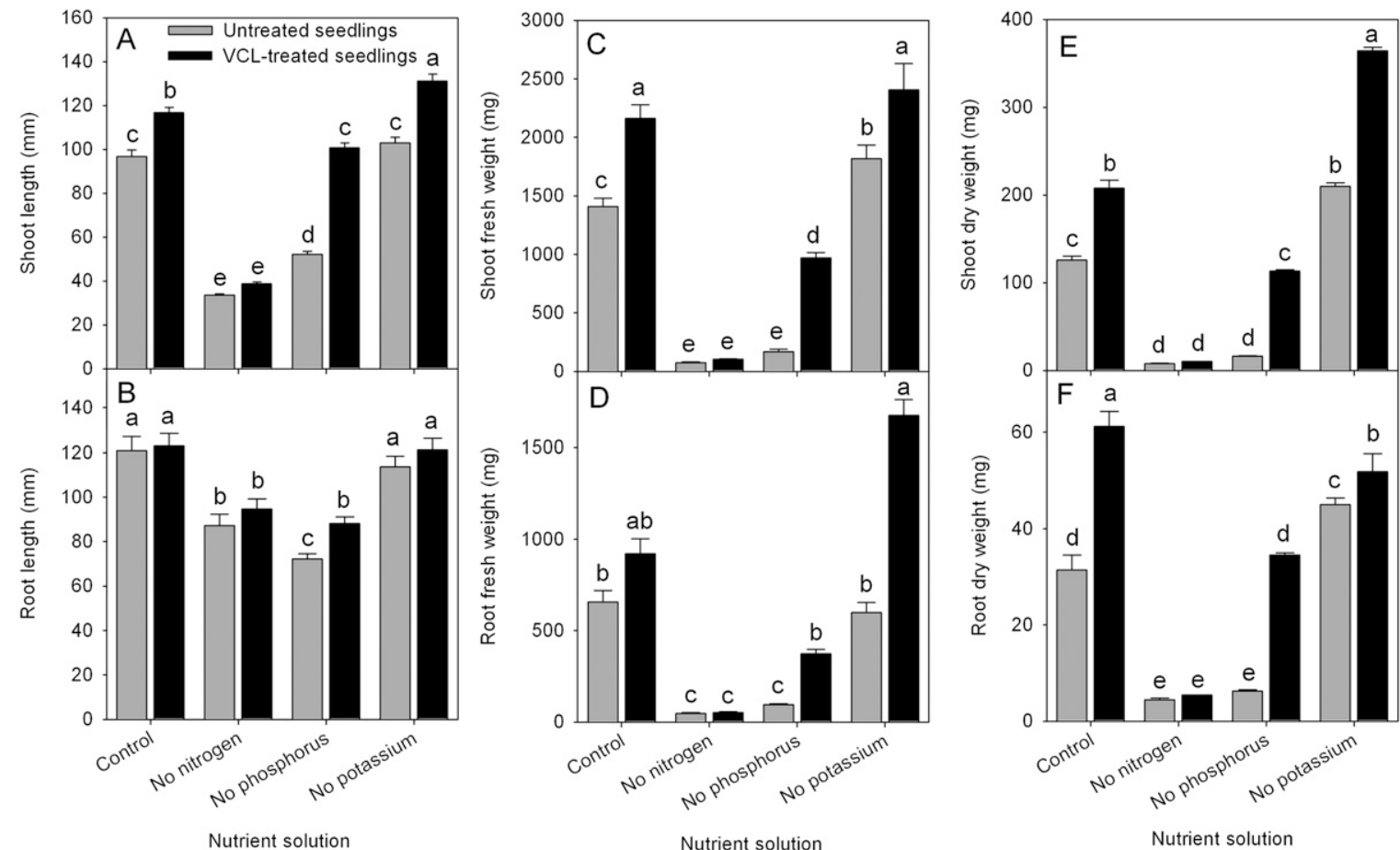

Fig. 1. (A-F) Effect of nutrient solution (50\% Hoagland's) and vermicompost leachate (VCL) with or without nitrogen, phosphorus, or potassium on different growth parameters of greenhouse-grown tomato seedlings $(\mathrm{n}=10)$. In each graph, bars with different letter(s) are significantly different based on Duncan's multiple test range test $(P=0.05)$. 


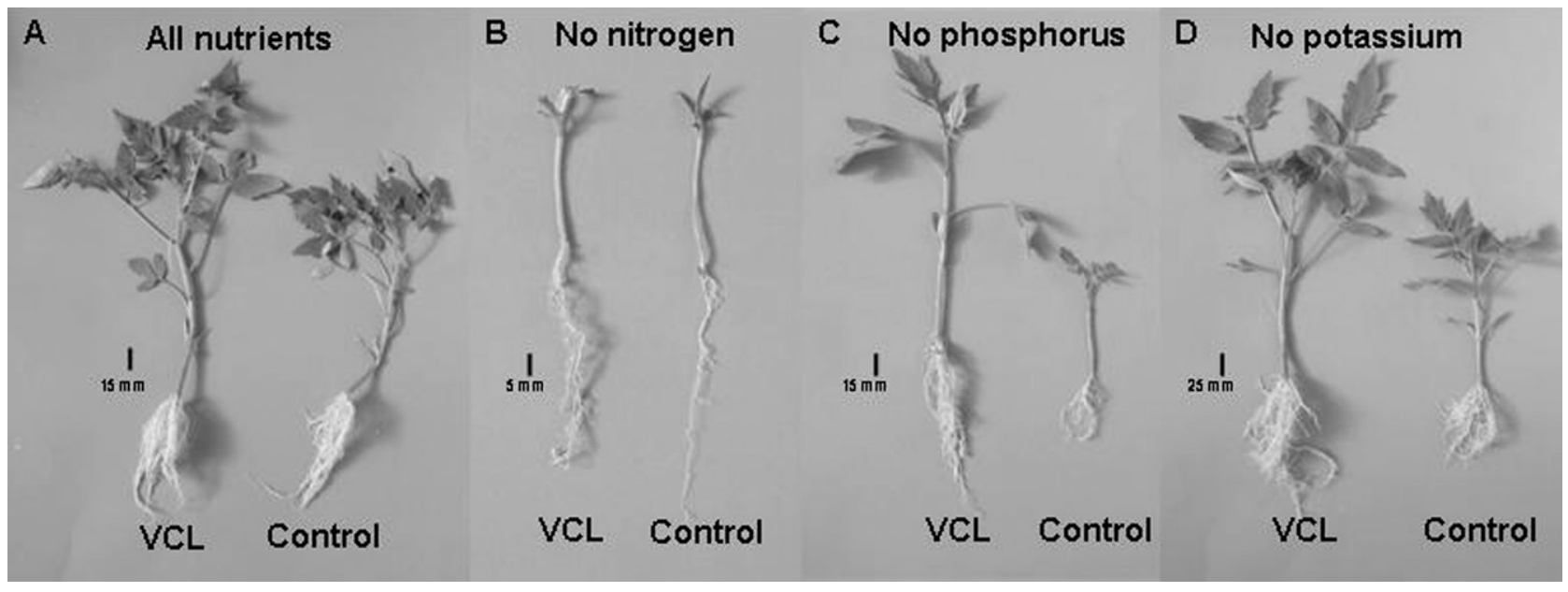

Fig. 2. (A-D) Tomato seedlings treated with nutrient solution (50\% Hoagland's) and vermicompost leachate (VCL) with or without nitrogen, phosphorus, or potassium. (A) Fifty percent Hoagland's nutrient solution, (B) 50\% Hoagland's nutrient solution without nitrogen; (C) 50\% Hoagland's nutrient solution without phosphorus, and (D) 50\% Hoagland's nutrient solution without potassium.

Table 1. Effect of nutrient solution (50\% Hoagland's) and vermicompost leachate (VCL) with or without nitrogen, phosphorus, or potassium on number of leaves and photosynthetic pigment contents of tomato seedlings grown under greenhouse conditions $(\mathrm{n}=10)$.

\begin{tabular}{lccccccc}
\hline Treatment & $\begin{array}{c}\text { Leaves } \\
(\text { no. })\end{array}$ & $\begin{array}{c}\text { Chlorophyll a } \\
\left(\mu \mathrm{g} \cdot \mathrm{g}^{-1} \mathrm{FW}\right)\end{array}$ & $\begin{array}{c}\text { Chlorophyll b } \\
\left(\mu \mathrm{g} \cdot \mathrm{g}^{-1} \mathrm{FW}\right)\end{array}$ & $\begin{array}{c}\text { Chlorophyll } \\
\mathrm{a} / \mathrm{b}\end{array}$ & $\begin{array}{c}\text { Total chlorophyll } \\
\left(\mu \mathrm{g} \cdot \mathrm{g}^{-1} \mathrm{FW}\right)\end{array}$ & $\begin{array}{c}\text { Carotenoid } \\
\left(\mu \mathrm{g} \cdot \mathrm{g}^{-1} \mathrm{FW}\right)\end{array}$ & $\begin{array}{c}\text { Total } \\
\mathrm{chlorophyll} / \mathrm{carotenoid}\end{array}$ \\
\hline Control & $5.2 \pm 0.1 \mathrm{~b}$ & $1143 \pm 11 \mathrm{a}$ & $517 \pm 14 \mathrm{~b}$ & $2.21 \pm 0.038 \mathrm{~d}$ & $1660 \pm 25 \mathrm{~b}$ & $335 \pm 3 \mathrm{a}$ & $4.94 \pm 0.043 \mathrm{~b}$ \\
No nitrogen & $1.0 \pm 0.0 \mathrm{e}$ & $153 \pm 5 \mathrm{e}$ & $58 \pm 2 \mathrm{e}$ & $2.65 \pm 0.030 \mathrm{~b}$ & $211 \pm 7 \mathrm{f}$ & $65 \pm 1 \mathrm{e}$ & $3.22 \pm 0.076 \mathrm{~d}$ \\
No phosphorus & $2.2 \pm 0.0 \mathrm{~d}$ & $691 \pm 28 \mathrm{~d}$ & $339 \pm 14 \mathrm{~d}$ & $2.03 \pm 0.015 \mathrm{e}$ & $1030 \pm 42 \mathrm{e}$ & $256 \pm 8 \mathrm{~d}$ & $4.00 \pm 0.053 \mathrm{c}$ \\
No potassium & $5.4 \pm 0.1 \mathrm{~b}$ & $1184 \pm 11 \mathrm{a}$ & $601 \pm 24 \mathrm{a}$ & $1.99 \pm 0.059 \mathrm{e}$ & $1785 \pm 34 \mathrm{a}$ & $330 \pm 3 \mathrm{a}$ & $5.39 \pm 0.096 \mathrm{a}$ \\
Control + VCL & $5.2 \pm 0.1 \mathrm{~b}$ & $1048 \pm 14 \mathrm{~b}$ & $431 \pm 11 \mathrm{c}$ & $2.43 \pm 0.034 \mathrm{c}$ & $1480 \pm 24 \mathrm{c}$ & $307 \pm 6 \mathrm{~b}$ & $4.82 \pm 0.087 \mathrm{~b}$ \\
No nitrogen + VCL & $1.0 \pm 0.0 \mathrm{e}$ & $205 \pm 14 \mathrm{e}$ & $73 \pm 5.3 \mathrm{e}$ & $2.83 \pm 0.035 \mathrm{a}$ & $278 \pm 19 \mathrm{f}$ & $82 \pm 5 \mathrm{e}$ & $3.36 \pm 0.071 \mathrm{~d}$ \\
No phosphorus + VCL & $3.7 \pm 0.1 \mathrm{c}$ & $989 \pm 43 \mathrm{bc}$ & $448 \pm 30 \mathrm{c}$ & $2.24 \pm 0.051 \mathrm{~d}$ & $1437 \pm 73 \mathrm{~cd}$ & $296 \pm 12 \mathrm{bc}$ & $4.83 \pm 0.041 \mathrm{~b}$ \\
No potassium + VCL & $5.9 \pm 0.1 \mathrm{a}$ & $976 \pm 23 \mathrm{c}$ & $380 \pm 16 \mathrm{~d}$ & $2.59 \pm 0.054 \mathrm{~b}$ & $1356 \pm 39 \mathrm{~d}$ & $281 \pm 7 \mathrm{c}$ & $4.81 \pm 0.038 \mathrm{~b}$ \\
\hline
\end{tabular}

Mean values $( \pm \mathrm{SE})$ in same column with different letter(s) are significantly different according to Duncan's multiple range test $(P=0.05)$.

$\mathrm{FW}=$ fresh weight.

and fertilizers remain pertinent (Lammerts van Bueren et al., 2011). As an indication of the importance of $\mathrm{N}$, the shoot fresh weight of $\mathrm{N}$-deficient tomato seedlings was $\approx 19$-fold lower than seedlings irrigated with $50 \%$ Hoagland's nutrient solution. As demonstrated in other studies (Ding et al., 2005; Zhao et al., 2005), $\mathrm{N}$ deficiency resulted in lower biomass and negatively affected overall growth of the tomato seedling. Generally, supplementing $50 \%$ Hoagland nutrient solution with VCL significantly enhanced the growth of the tomato seedlings compared with controls. In particular, the beneficial effect was most prominent in the absence of $\mathrm{P}$ in the nutrient solution where the shoot and root dry weights of VCL-irrigated tomato seedlings were approximately seven- and sixfold higher, respectively, than the control seedlings. Similar stimulatory effects of vermicompost have been demonstrated in several species such as bananas (Aremu et al., 2012; Padmavathiamma et al., 2008), marigolds (Sangwan et al., 2010), and amaranth (Alam et al., 2007). Often, the stimulatory effect has been attributed to the presence of mineral elements, humic acid, and plant hormone-like compounds in vermicompost (Arancon et al., 2003; Campitelli and Ceppi, 2008; Suthar, 2010; Tomati et al., 1988). It has been postulated that humic compounds affect plant growth by increasing anion and cation uptake, protein synthesis, and the action of nitrate metabolism enzymes (Suthar, 2010). As summarized by Ievinsh (2011), humic compounds could either bind a number of mineral nutrient, releasing them during degradation, or act as a possible candidate for non-nutritional growth-promoting substances in vermicompost preparations. The presence of humic acid in a novel organomineral fertilizer enhanced the nutrient status of tomato plants under greenhouse conditions (Rady, 2012). On the other hand, comparable amounts of growth-regulating substances, which are found in soil and rhizosphere of many plants, are present in earthworm egesta (Lynch, 1979). The presence of similar compounds and growth-promoting substances could have partly contributed to the improved growth of tomato seedlings in the current study.

Both positive and negative effects of vermicompost on photosynthetic pigments have been reported in different plant species. Ievinsh (2011) and Uma and Malathi (2009) observed a stimulatory effect of vermicompost on chlorophyll content. In contrast, there was a decrease in chlorophyll content of lettuce grown in $100 \%$ vermicompost (Ali et al., 2007). In this study, $\mathrm{N}$ deficiency had the most pronounced detrimental effect on the photosynthetic pigment content. However, the addition of VCL slightly improved the pigment levels detected in the tomato seedlings. The importance of $\mathrm{N}$ during plant growth is well known; for instance, $\mathrm{N}$ deficiency decreased chlorophyll content and photosynthetic rate in sorghum (Zhao et al., 2005) and maize (Ding et al., 2005). Based on evidence from this study, there is a clear indication that the use of VCL cannot alleviate the effect of $\mathrm{N}$ deficiency during the growth of tomatoes.

Apart from a potassium deficiency and VCL supplementation, there was an increase in photosynthetic pigment content of VCLtreated tomato seedlings in the present study. However, the reduced photosynthetic pigment content had no negative effect on seedling growth; a similar result was also observed in lettuce grown using 100\% vermicompost (Ali et al., 2007). Generally, changes in chlorophyll content are regarded as a relatively late event, which remains an independent mechanism of photosynthetic adaptation (Alonso et al., 2002). Remarkably, in terms of the chlorophyll a/b (photosynthetic efficiency) and total chlorophyll/carotenoid (degree of greenness) ratios, the majority of the VCL-treated tomato seedlings were significantly superior to their respective controls. In an attempt to overcome stress conditions, various physiological mechanisms are triggered within the plant as an adaptive measure. The rate of individual photosynthetic pigments is altered resulting in changes in the chlorophyll a/b ratio, presumably as an adaptive response to maximize the 
light-harvesting capability of the chloroplast apparatus (Chow et al., 1990).

Current findings suggest that the use of VCL could easily serve as a substitute for $\mathrm{P}$ and $\mathrm{K}$ for the growth of tomatoes. Vermicompost leachate is more environmental-friendly and can be a convenient method of application for tomato growers, which would inevitably improve tomato production. Vermicompost leachate can be less expensive and will assist in minimizing the use of chemical fertilizers.

\section{Literature Cited}

Alam, M.N., M.S. Jahan, M.K. Ali, M.S. Islam, and S.M.A.T. Khandaker. 2007. Effect of vermicompost and NPKS fertilizers on growth, yield and yield components of red amaranth. Austal. J. Basic Appl. Sci. 1:706-716.

Ali, M., A.J. Griffiths, K.P. Williams, and D.L. Jones. 2007. Evaluating the growth characteristics of lettuce in vermicompost and green waste compost. Eur. J. Soil Biol. 43:S316-S319.

Alonso, M., M.J. Rozados, J.A. Vega, P. PérezGorostiaga, P. Cuiñas, M.T. Fontúrbel, and C. Fernández. 2002. Biochemical responses of Pinus pinaster trees to fire-induced trunk girdling and crown scorch: Secondary metabolites and pigments as needle chemical indicators. J. Chem. Ecol. 28:687-700.

Arancon, N.Q., S. Lee, C.A. Edwards, and R. Atiyeh. 2003. Effects of humic acids derived from cattle, food and paper-waste vermicomposts on growth of greenhouse plant. Pedobiologia (Jena) 47:741-744.

Aremu, A.O., M.G. Kulkarni, M.W. Bairu, J.F. Finnie, and J. Van Staden. 2012. Growth stimulation effects of smoke-water and vermicompost leachate on greenhouse grown-tissuecultured 'Williams' bananas. Plant Growth Regulat. 66:111-118.

Bachman, G.R. and J.D. Metzger. 2008. Growth of bedding plants in commercial potting substrate amended with vermicompost. Bioresour. Technol. 99:3155-3161.

Campitelli, P. and S. Ceppi. 2008. Chemical, physical and biological compost and vermicompost characterization: A chemometric study. Chemom. Intell. Lab. Syst. 90:64-71.

Chow, W.S., J.M. Anderson, and A. Melis. 1990. The photosystem stoichiometry in thylakoids of some Australian shade-adapted plant species. Aust. J. Plant Physiol. 17:665-674.

Ding, L., K.J. Wang, G.M. Jiang, D.K. Biswas, H. $\mathrm{Xu}$, L.F. Li, and Y.H. Li. 2005. Effects of nitrogen deficiency on photosynthetic traits of maize hybrids released in different years. Ann. Bot. (Lond.) 96:925-930.
Gutiérrez-Miceli, F.A., R.C. García-Gómez, R. Rincón Rosales, M. Abud-Archila, O.L. María Angela, M.J.G. Cruz, and L. Dendooven. 2008. Formulation of a liquid fertilizer for sorghum [Sorghum bicolor (L.) Moench] using vermicompost leachate. Bioresour. Technol. 99:6174 6180.

Hebbar, S.S., B.K. Ramachandrappa, H.V Nanjappa, and M. Prabhakar. 2004. Studies on NPK drip fertigation in field grown tomato (Lycopersicon esculentum Mill.). Eur. J. Agron. 21:117-127.

Hoagland, D.R. and W.C. Snyder. 1933. Nutrition of strawberry plants under controlled conditions. Proc. Am. Soc. Hortic. Sci. 30:288-296.

Ievinsh, G. 2011. Vermicompost treatment differentially affects seed germination, seedling growth and physiological status of vegetable crop species. Plant Growth Regulat. 65: 169-181.

Lammerts van Bueren, E.T., S.S. Jones, L. Tamm, K.M. Murphy, J.R. Myers, C. Leifert, and M.M. Messmer. 2011. The need to breed crop varieties suitable for organic farming, using wheat, tomato and broccoli as examples: A review. NJAS-Wagen. J. Life Sci. 58: 193-205.

Lazcano, C., P. Revilla, R.A. Malvar, and J. Domínguez. 2011. Yield and fruit quality of four sweet corn hybrids (Zea mays) under conventional and integrated fertilization with vermicompost. J. Sci. Food Agr. 91:1244 1253.

Lichtenthaler, H.K. 1987. Chlorophylls and carotenoids: Pigments of photosynthetic biomembranes, p. 350-382. In: Douce, R. and L. Packer (eds.). Methods in enzymology. Vol. 148. Academic Press, New York, NY.

Lockie, S., K. Lyons, G. Lawrence, and K. Mummery. 2002. Eating 'Green': Motivations behind organic food consumption in Australia. Sociol. Ruralis 42:23-40.

Lynch, J.H. 1979. The terrestrial environment, p. 67-91. In: Lynch, J.H. and H.J. Poole (eds.). Microbial ecology-A conceptual approach. Blackwell, London, UK

Lyson, T.A. 2002. Advanced agricultural biotechnologies and sustainable agriculture. Trends Biotechnol. 20:193-196.

Padmavathiamma, P.K., L.Y. Li, and U.R. Kumari. 2008. An experimental study of vermi-biowaste composting for agricultural soil improvement. Bioresour. Technol. 99:1672-1681.

Paul, L.C. and J.D. Metzger. 2005. Impact of vermicompost on vegetable transplant quality. HortScience 40:2020-2023.

Premuzic, Z., M. Bargiela, A. Garcia, A. Rendina, and A. Iorio. 1998. Calcium, iron, potassium, phosphorus, and vitamin $\mathrm{C}$ content of organic and hydroponic tomatoes. HortScience 33: 255-257.

Rady, M.M. 2012. A novel organo-mineral fertilizer can mitigate salinity stress effects for tomato production on reclaimed saline soil. S. Afr. J. Bot. 81:8-14.

Roosta, H.R. and M. Hamidpour. 2011. Effects of foliar application of some macro- and micronutrients on tomato plants in aquaponic and hydroponic systems. Sci. Hort. 129:396-402.

Sangwan, P., V. Garg, and C. Kaushik. 2010. Growth and yield response of marigold to potting media containing vermicompost produced from different wastes. Environmentalist 30:123-130.

Sato, S., S. Sakaguchi, H. Furukawa, and H. Ikeda. 2006. Effects of $\mathrm{NaCl}$ application to hydroponic nutrient solution on fruit characteristics of tomato (Lycopersicon esculentum Mill.). Sci. Hort. 109:248-253.

Surrage, V.A., C. Lafrenière, M. Dixon, and Y. Zheng. 2010. Benefits of vermicompost as a constituent of growing substrates used in the production of organic greenhouse tomatoes. HortScience 45:1510-1515.

Suthar, S. 2010. Evidence of plant hormone-like substances in vermiwash: An ecologically safe option of synthetic chemicals for sustainable farming. Ecol. Eng. 36:1089-1092.

Tilman, D., K.G. Cassman, P.A. Matson, R. Naylor, and S. Polasky. 2002. Agricultural sustainability and intensive production practices. Nature 418:671-677.

Tomati, U., E. Galli, A. Grappelli, and G. Lena. 1990. Effect of earthworm casts on protein synthesis in radish (Raphanus sativum) and lettuce (Lactuca sativa) seedlings. Biol. Fertil. Soils 9:288-289.

Tomati, U., A. Grappelli, and E. Galli. 1988. The hormone-like effect of earthworm casts on plant growth. Biol. Fertil. Soils 5:288-294.

Uma, B. and M. Malathi. 2009. Vermicompost as a soil supplement to improve growth and yield of Amaranthus species. Res. J. Agr. Biol. Sci. 5:1054-1060.

Wang, D., Q. Shi, X. Wang, M. Wei, J. Hu, J. Liu, and F. Yang. 2010. Influence of cow manure vermicompost on the growth, metabolite contents, and antioxidant activities of Chinese cabbage (Brassica campestris ssp. chinensis). Biol. Fertil. Soils 46:689-696.

Welch, R.M. and R.D. Graham. 1999. A new paradigm for world agriculture: Meeting human needs: Productive, sustainable, nutritious. Field Crops Res. 60:1-10.

Zhao, D., K.R. Reddy, V.G. Kakani, and V.R. Reddy. 2005. Nitrogen deficiency effects on plant growth, leaf photosynthesis, and hyperspectral reflectance properties of sorghum. Eur. J. Agron. 22:391-403. 